\title{
Reinventing public transport system in Luxembourg and its implications for foreign tourists
}

Toshihiko Shimauchi (Faculty of Intercultural Communication, Komatsu University, toshihiko.shimauchi@komatsu-u.ac.jp)

\begin{abstract}
Luxembourg has two distinctive issues in terms of mobility: the highest number of car per capita in the country and 120,000 international commuters per day from three surrounding countries (Germany, France, and Belgium). These issues lead to traffic congestion during rush hour and air pollution. The new initiative aims to give incentive to the residents and commuters to use public transport. Although these programs are mainly intended for these daily users, they could exert positive implications for tourists visiting the country. A new tram system could make it easy to travel from the airport to the accommodations. Also, since the system is easier to understand than bus routes, tourists' area of activities would expand.
\end{abstract}

\section{Keywords}

mobility, public transport, LRT, SDGs, smart city

\section{Introduction}

Luxembourg (officially Grand Duchy of Luxembourg) is the wealthiest among the OECD countries with GDP per capita of US\$ 120,980 in 2019 [OECD Data, n.d.]. The steel industry was the origin of the country's wealth and since 1869s until 1960s, the industry had been an important part of the country and the motor of modernization. Since 1960s, the government has started economic structural reform, with strong emphasis on finance sector. Currently, the Luxembourg is one of the largest financial center, allowing the country to become the wealthiest country in the world.

This economic success has aroused several economic and social problems. Among them, traffic congestion and accompanying air pollution are two of the largest ones.

Due to the economic success, the population has been growing rapidly. Most of them are social increase from the surrounding countries. The housing construction has been outpaced by this population growth [OECD, 2020]. This mismatch also leads to the higher housing prices. For example, owneroccupied housing price index has risen from 82.69 in 2010 to 121.91 in 2019 [Eurostat, 2020c]. That is the increase of nearly $50 \%$ in ten years.

This rapid rising housing price has led to housing development in rural areas and the traffic congestions in and around the city center at peak times. The traffic congestion is one of the main reasons for the high $\mathrm{CO}_{2}$ emissions per capita (14.8 tonnes in 2017) [OECD, n.d.].

Another issue facing the country is the size of the frontier workers [Eurofound, 2018], who live in the surrounding three countries (Germany, France and Belgium) and commute to workplaces in Luxembourg every day. The number of the frontier workers is more than 200,000 [Toussaint, 2019]. Their main mode of commuting is private car, exacerbating traffic problems in the center.

In 2018, Luxembourg had the highest number of passenger cars per inhabitant in the EU, with 676 cars per 1,000 inhabitants [Eurostat, 2020b]. Approximately $60 \%$ of these cars run on diesel fuel [Eurostat, 2020a].

A diesel engine uses, in principle, less fuel and produces less carbon dioxide than a petrol engine with the same power output. However, the engines produce higher levels of particulates which can penetrate deep into the lungs, causing irritation and potentially triggering asthma attacks [Leggett, 2018].

\section{Mobility strategy}

To address these issues, the successive governments of Luxembourg have been trying to promote modal shift and encouraging people to use public transport instead of private cars.

\subsection{MoDu (2012)}

In 2012, "Modu" strategy was established [Le gouvernement luxembourgeois, 2012]. The economic development over past 30 years had been accompanied by rapid increase of jobs. However, the development was geographically unbalanced, so the need for mobility had been also rising. Several measures such as road expansions and extensions had been implemented, but these were not sufficient to meet the mobility demand. This situation negatively impacted the quality of life, the environment and the economy of the country.

The response to this demand required a global restructuring of the supply of public transport - especially in and around the Luxembourg City.

In this strategy, the tram system was identified as the core element of a new organization of public transport. The system was expected to meet several objectives:

- To strengthen the attractiveness and efficiency of public transport, through an flexible offer in terms of capacity, regularity and comfort and through better structured and optimized inter-modality of all modes of travel;

- To constitute a real lever for actions for the sustainable development policy, both with respect for the environment due to the technologies deployed, and with regard to social 
cohesion, thanks to better accessibility and redesigned interneighbourhood relations;

- To support major current and future urban development projects, by offering quality services to the various development poles in and around the city of Luxembourg.

\subsection{Modu 2.0 (2018)}

A national survey on mobility was conducted in 2017 and based on the findings, a new mobility policy called Modu 2.0 Strategy for sustainable mobility was implemented in 2018 [Le gouvernement luxembourgeois, 2018].

While the fundamental principles of the former "MoDu" strategy in 2012 remain in force (multimodality and the strengthening of public transport and active modes), the new strategy sets targets for 2025, incorporates recent technological advances, and ensures consistency with new global and national strategies, such as Paris Climate Agreement.

The strategic objective for 2025 is to reduce congestion at peak times while transporting $20 \%$ more people than in 2017. This overall objective is broken down into following four specific quantified goals (Table 1 and Figure 1).

\section{Tramways \\ 3.1 History}

A first horse-drawn tram operated in the Luxembourg City in February, 1875 [Musée de Tramways et de Bus de la Ville de Luxembourg, n.d.]. From then till 1908, the city had a network of horse-drawn trams that covered 10 kilometres (Figure 2).

An electric tram network was launched in August 1908 and this brought about the end of horse-drawn trams. The horsedrawn trams ran on $1435-\mathrm{mm}$ gauge, while the newly introduced electric trams had 1000-mm gauge size. This change in gauge size led to a complete replacement of the existing infrastructure (Figure 3).

Due to the rise of motorization after the World War II, the electric trams were replaced by buses on September 5, 1964.

Table 1: Objectives and actions in Modu 2.0

\begin{tabular}{|c|c|}
\hline Goals & Actions \\
\hline 1. Modal shares of home-work trips & $\begin{array}{l}\text { - Increase the number of public transport passengers by } 50 \% \text { through the commissioning of } \\
\text { the new railway infrastructures and the reorganization of the bus network. } \\
\text { - Make } 95 \% \text { of home-work trips of less than } 1 \mathrm{~km} \text { on foot }(56 \% \text { in } 2017) \text {. } \\
\text { - Cycle } 10 \% \text { of home-work trips of less than } 5 \mathrm{~km}(5 \% \text { in } 2017) \text {. }\end{array}$ \\
\hline 2. Car occupancy rate & - Increase the average occupancy rate for home-work trips to 1.5 people per car (1.2 in 2017). \\
\hline 3. Modal share of home-school trips & $\begin{array}{l}\text { - Make } 75 \% \text { of home-school trips of less than } 1 \mathrm{~km} \text { on foot }(58 \% \text { in } 2017) \text {. } \\
\text { - Cycle } 15 \% \text { of home-school trips of less than } 5 \mathrm{~km}(3 \% \text { in } 2017) \text {. } \\
\text { - Make } 50 \% \text { of home-primary school trips by bus ( } 29 \% \text { in } 2017) \text { Make } 77 \% \text { of home- } \\
\text { secondary school trips by bus or train ( } 70 \% \text { in } 2017) \text {. }\end{array}$ \\
\hline 4. Attractiveness of public transport & $\begin{array}{l}\text { - Eliminate less than } 1 \text { train in } 100 \text { ( } 1 \text { train in } 40 \text { was deleted in 2017). } \\
\text { - Reduce the share of trains six minutes or more behind by } 25 \% \text { (compared to 2017). } \\
\text { - Achieve shorter than car journey times for rush hour express bus lines between the first } \\
\text { stop and the terminals. }\end{array}$ \\
\hline
\end{tabular}

Goal 1

Modal split of the work routes.

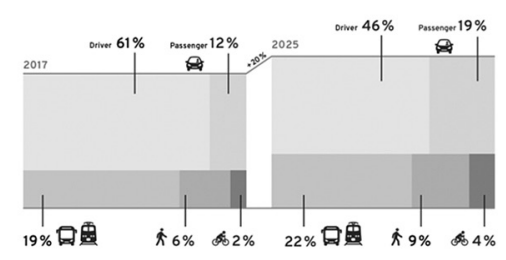

Goal 3

Modal split of the school routes.

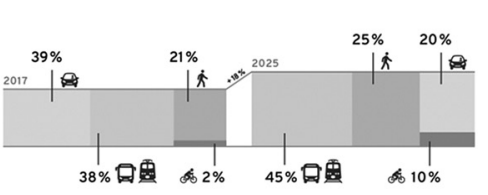

Goal 2

Increase the average occupancy rate for the distances between home and workplace to 1.5 persons per car (1.2 in 2017). This corresponds to 'two persons in each second car'.

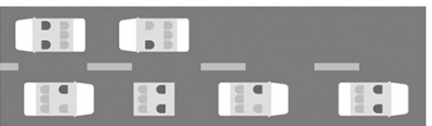

\section{Goal 4}

Make public transport more attractive.

\section{$1 / 100$ \\ Make less than one of 100 trains fail \\ (in 2017, one of 40 trains failed) \\ Reduce the proportion of train service with a delay of six minutes or more (compared to 2017 ) by $25 \%$ \\ $25 \%$}

Eake sure that express bus travel times between the first stop and the terminus at peak hours are shorter terminus at peak hours are
than those for private cars.

Figure 1: Goals of Modu 2.0 


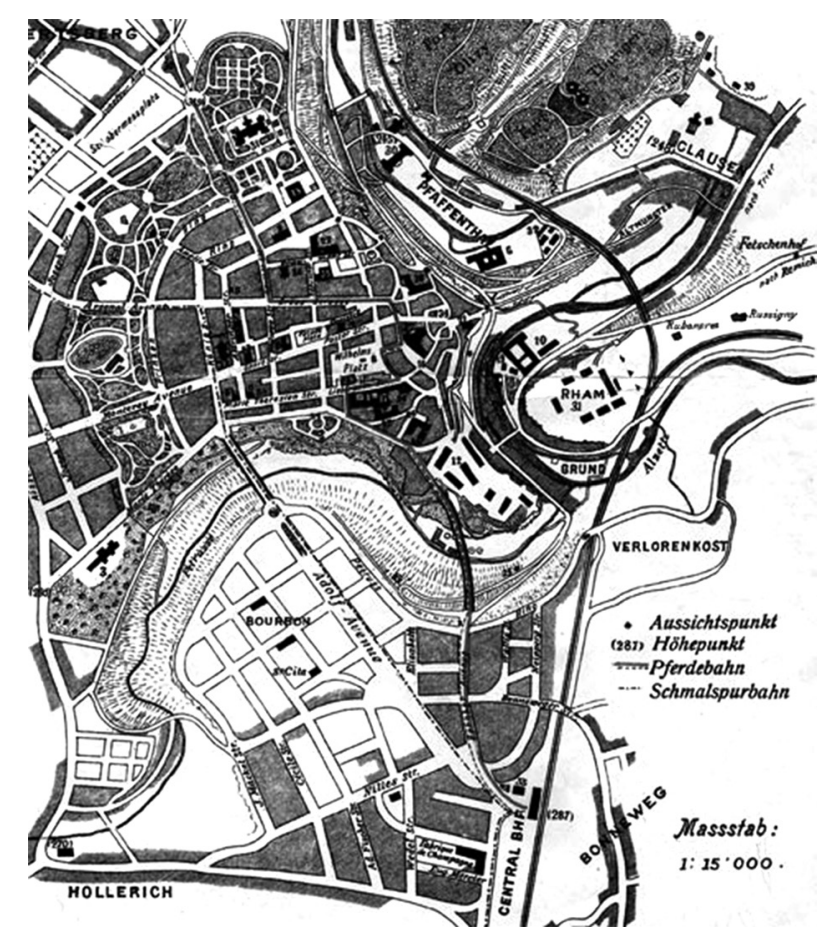

Figure 2: First horse tram line

Source: Musée de Tramways et de Bus de la Ville de Luxembourg.

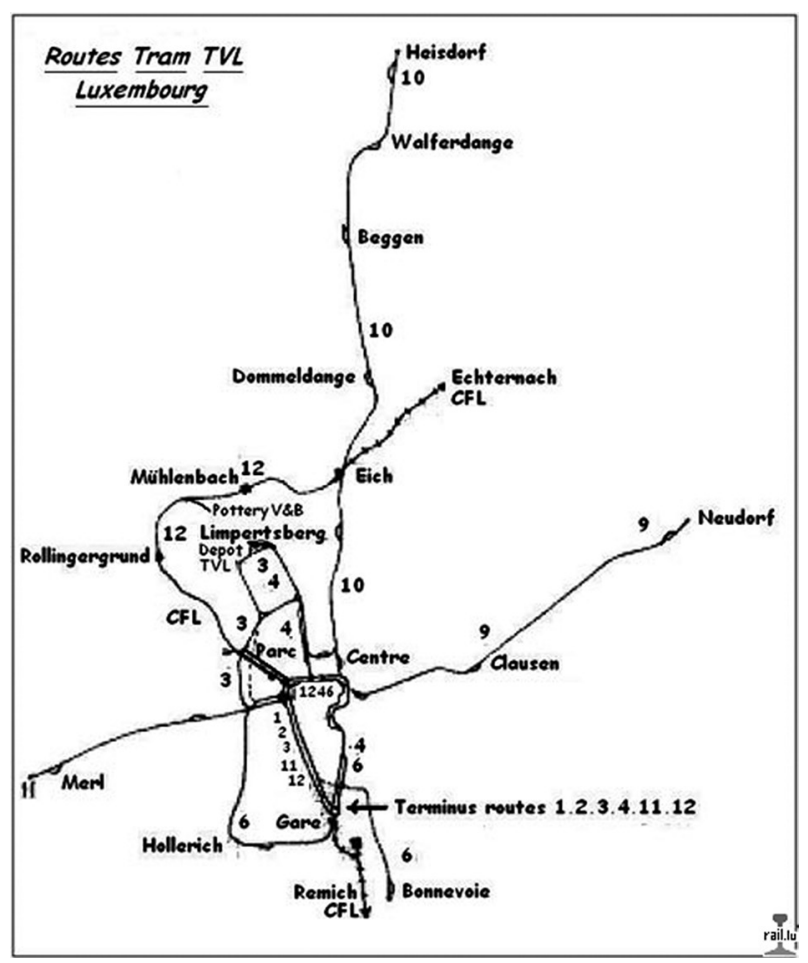

Figure 3: Electric tram network (Line no. 1, 2, 3, 4, 11, and 12) Source: Musée de Tramways et de Bus de la Ville de Luxembourg.

\subsection{Current system}

Since late 1990s, several initiatives were considered to reintroduce tram system. However, each initiative was not realized due to public oppositions.
Finally in June 2014, the Luxembourg congress voted in favour of the financing of the tram. Almost all of the deputies (56 out of 60) supported the construction of the first part of the line going from the Central Station in the historic district to Luxexpo in Kirchberg (new business district). At the same time, the decision was taken to build a new train station at the foot of the bridge connection the the historic district and Kirchberg as well as a funicular line providing access to the Kirchberg plateau [Le gouvernement luxembourgeois, n.d.].

In December 2017, the tram system was partial started its operation with 8 stations. Also, the new railway station and the bridge funicular line became operational.

\subsubsection{Service}

Currently, the tram operates between a station at the north end of the historic district (Stäreplaz-Étoile) and a station near the exhibition facility (Luxexpo) at the east end of the business district (Figure 4). The construction is underway to extend to the central station in the historic district. The goal is to connect the airport (Findel Aeroport) with a station in the newly developed business district in the south (Cloche d'Or). Total length under the current plan is $16 \mathrm{~km}$. In 2018, average number of users were 22,000 per day in weekdays [Luxtram, 2019].

On weekdays, the tram operates every 7 to 15 minutes according to the time of the day. On weekends, operating intervals extends to every 10 to 15 minutes due to decrease in commuting users.

\subsubsection{Survey}

Two surveys were conducted after the tram started to provide the service: one in January/February and the other in July/ August [TNS ILRES, 2018a; 2018b]. Approximately 1,000 residents over the age of 18 participated in each survey. Nearly $80 \%$ of the residents knew about the tram system and $85 \%$ responded that the system was a good concept for enhancing mobility. More than $70 \%$ responded they intended to use public transportation more often with the introduction of tram system.

However, actual usage was much lower. In January/February survey, $72 \%$ responded they had not yet used the tram. The number improved slightly to $56 \%$ in the second survey. Those who responded to use the tram regularly was lower than $5 \%$.

Satisfaction was significantly high among the residents who actually used the tram. Operation frequency, the course, comfortability, design and the station received more than $85 \%$ satisfaction. The highest aspect was the design of the train.

\subsubsection{Design}

One of the unique features of the carriage is colourful design to attract more users. Design is very important factor in marketing [Bruce and Daly, 2007]. Design influences people's perception and raises attentions and interests to new merchandises or projects. Based on AIDA model in marketing theory, attention and interest are the two important factors to induce potential users to become actual users. Cutting old habit of us- 


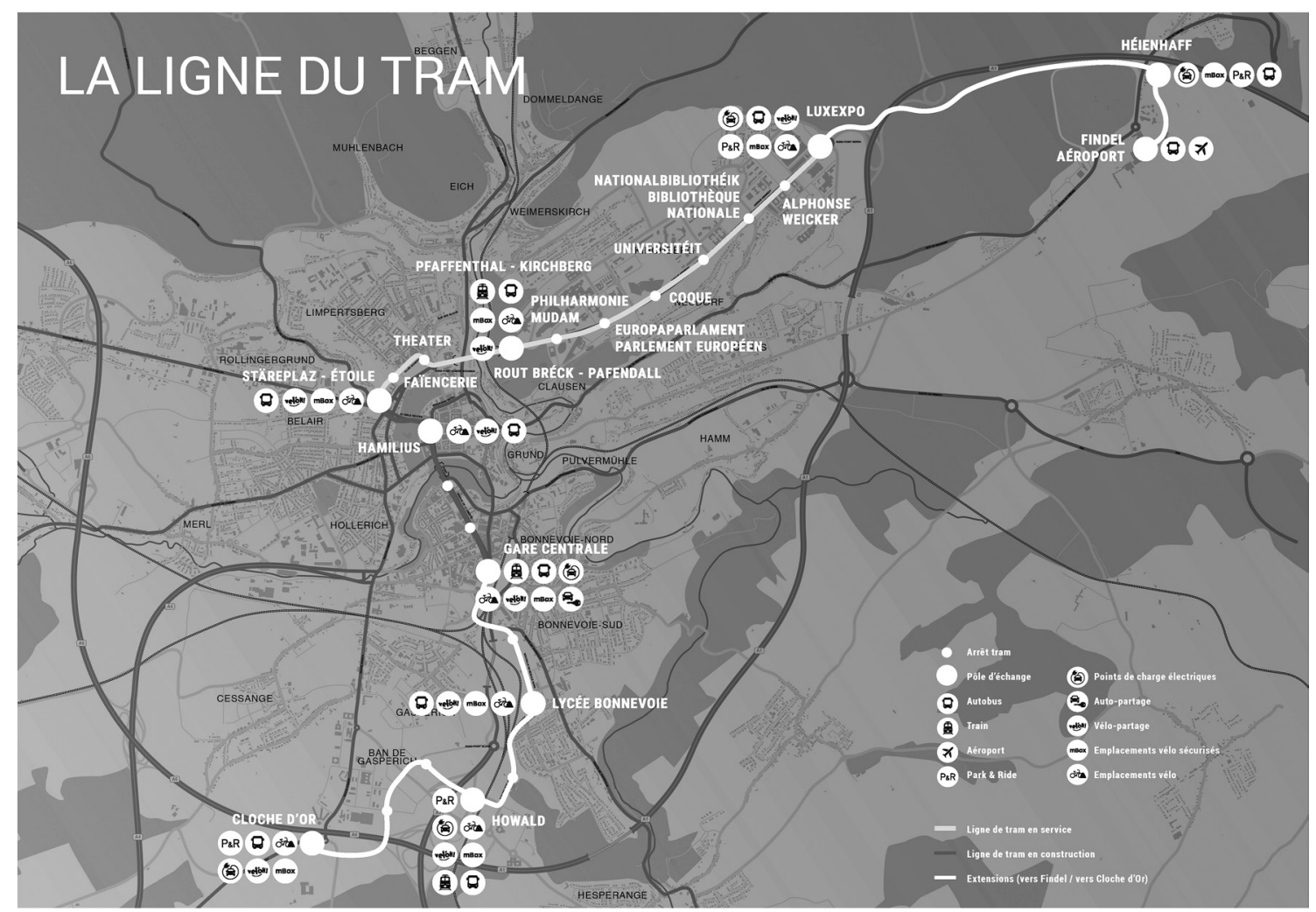

Figure 4: Tram line map

Source: Luxtram.

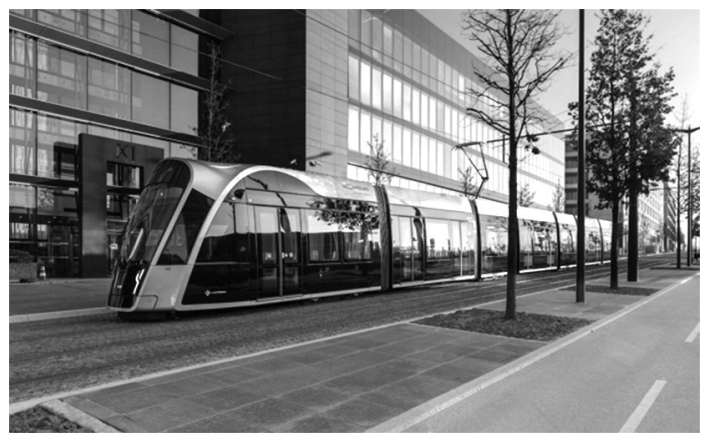

Figure 5: Tram design (Exterior) Source: Luxtram.

ing private cars is not easy. Design plays an important part in realizing a modal shift from private cars to public transport.

\subsection{Implications for tourism}

Although tram system is mainly intended for the residents and frontier workers, the system has potential benefits to tourists visiting Luxembourg.

Currently, there is only one bus line connecting the airport and the city center. The distance between them is approximately $10 \mathrm{~km}$ and costs 30 euro by taxi, which is high for the distance. With the planned opening of the whole tram system from the airport to the station area, it would become much easier and quicker for the independent foreign tourists to move to their accommodations.

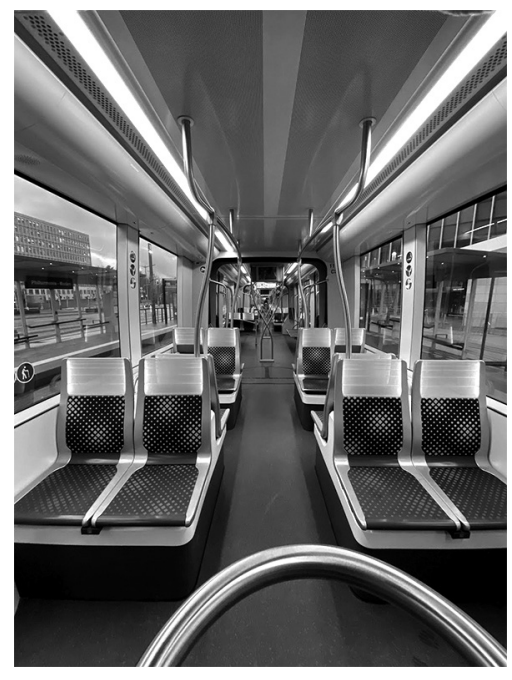

Figure 6: Tram design (Interior)

The trip from the business district and the historic district has already become convenient with the partial opening of the tram system. The historic district is designated as UNESCO Heritage Site and has many tourist spots to visit. Many restaurants and cafes are located in this district, too. For the accommodations, some hotels can be found in the district, but large and modern hotels are mainly situated in the business district. Two districts are $2 \mathrm{~km}$ away. There are already many buses but tourists' knowledge of the bus service is limited compared to the local residents [Bajada and Titheridge, 2017]. For tourists 
staying at hotels in the new city area, the tram offers convenient way to visit the historic district.

\section{Conclusion}

Luxembourg has been faced with traffic congestion and air pollution due to housing development in rural areas and high number of frontier workers. The tram system reintroduced in 2017 is one of the solutions to these problems. Although the system is still under construction, partial service already produces high satisfactions among the local residents. Design is one of the factors behind this high satisfaction. The tram system is intended mainly for the local residents, but tourists can also benefit from this new project.

This paper report one aspect of the reorganization in transportation policy in Luxembourg. In March 2020, all the public transportation system has become free of charge for everyone. This drastic new policy could have certain impact on the use of public transport. At the same time, since the COVID-19 epidemic, bicycle has been attracting renewed interest as a mode of daily transport. The effect of these new policy and development require further research.

\section{References}

Bajada, T. and Titheridge, H. (2017). The attitudes of tourists towards a bus service: Implications for policy from a Maltese case study. Transportation Research Procedia, Vol. 25, 4110-4129.

Bruce, M. and Daly, L. (2007). Design and marketing connections: Creating added value. Journal of Marketing Management, Vol. 23, No. 9-10, 929-953.

Eurofound (2018). Frontier worker (Retrieved September 9, 2020 from https://www.eurofound.europa.eu/observatories/ eurwork/industrial-relations-dictionary/frontier-worker).

Eurostat (2020a). Passenger cars, by type of motor energy (Retrieved September 9, 2020 from https://ec.europa.eu/eurostat/web/products-datasets/-/road_eqs_carpda).

Eurostat (2020b). Passenger cars in the EU: Statistics explained (Retrieved August 29, 2020 from https://ec.europa.eu/eurostat/statistics-explained/index.php/Passenger_cars_in_the_ EU\#Highest_number_of_passenger_cars_per_inhabitant_ in_Luxembourg).

Eurostat (2020c). Owner-occupied housing price index (2015=100): Annual data (Retrieved September 2, 2020 from https://ec.europa.eu/eurostat/databrowser/view/prc hpi_ooa/default/table?lang=en).

Le gouvernement luxembourgeois (n.d.). Planning de réalisation (Retrieved September 9, 2020 from http://transports. public.lu/fr/mobilite/transports-collectifs/tram/tram/planning.html).

Le gouvernement luxembourgeois (2012). MoDu: Stratégie globale pour une mobilité durable pour les résidents et les frontaliers (Retrieved September 10, 2020 from http://transports.public.lu/fr/contexte/strategie/modu1.html).

Le gouvernement luxembourgeois (2018). Modu 2.0: Stratégie pour une mobilité durable (Retrieved September 10, 2020 from http://transports.public.lu/fr/contexte/strategie/modu2. html).

Leggett, T. (2018, January 21). Air pollution: Are diesel cars always the biggest health hazard? BBC News (Retrieved September 2, 2020 from https://www.bbc.com/news/scienceenvironment-42666596).

OECD (n.d.). Luxembourg: OECD Data Retrieved September 2, 2020 (Retrieved September 2, 2020 from http://data.oecd. org/luxembourg.htm).

OECD. (2020). OECD Economic Surveys: Luxembourg 2019 (Retrieved September 2, 2020 from https://www.oecd-ilibrary.org/economics/oecd-economic-surveys-luxembourg2019_424839c1-en).

Luxtram (2019). Rapport d'activite 2018.

Musée de Tramways et de Bus de la Ville de Luxembourg (n.d.). TVL: Tramways de la Ville de Luxembourg (1875-19081964) (Retrieved September 10, 2020 from https://rail.lu/tvl. html).

TNS ILRES (2018a). L'opinion publique face au projet du tramway a Luxembourg (Retrieved September 9, 2020 from http://www.luxtram.lu/wp-content/uploads/Sondage-TNSILRES-Tram-barometer-MDDI-conf\%C3\%A 9rence-depresse-mars-2018-PDF.pdf).

TNS ILRES (2018b, September). L'opinion publique face au projet du tramway a Luxembourg (Retrieved September 9, 2020 from http://transports.public.lu/fr/publications/transports-collectifs/tram.html).

Toussaint, T. (2019, September 3). 200,000 cross-border workers in Luxembourg (Retrieved September 9, 2020 from https://today.rtl.lu/news/luxembourg/a/1398145.html).

\section{Appendix}

A new funicular line connects the stations of the tram and the railway systems in 63 seconds. Their elevation difference is 40 meters. The length of the line is approximately 200 meters. The funicular is fully automated and the maximum capacity is 168 people (Figures 7-10).

One of the aims for introducing the tram system is to real-

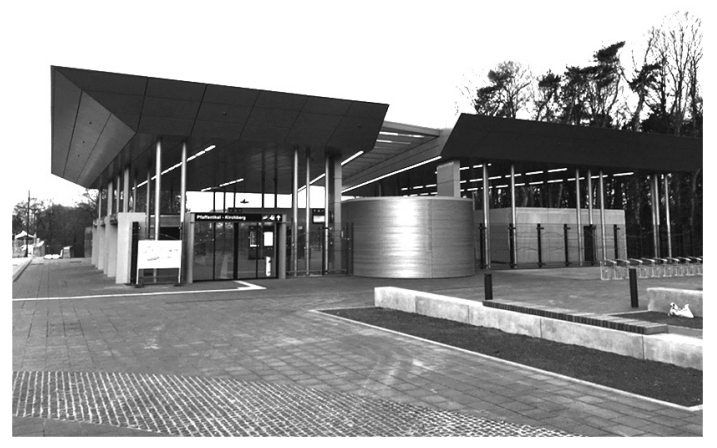

Figure 7: Funicular station (Tram side) 


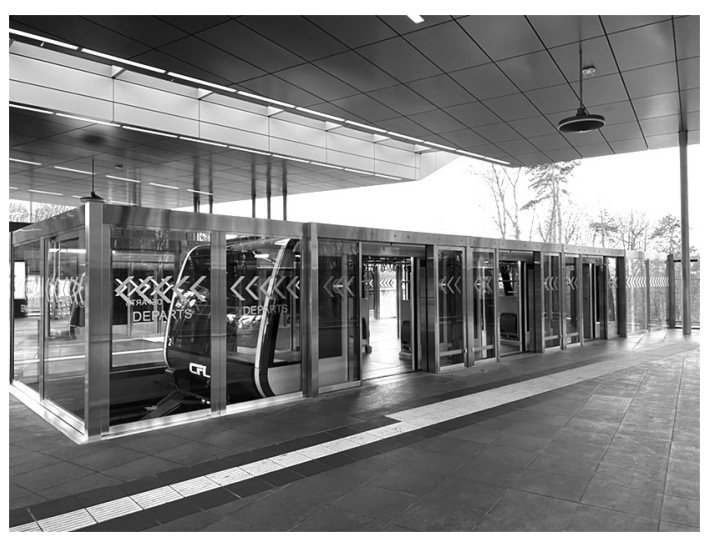

Figure 8: Funicular (Exterior)

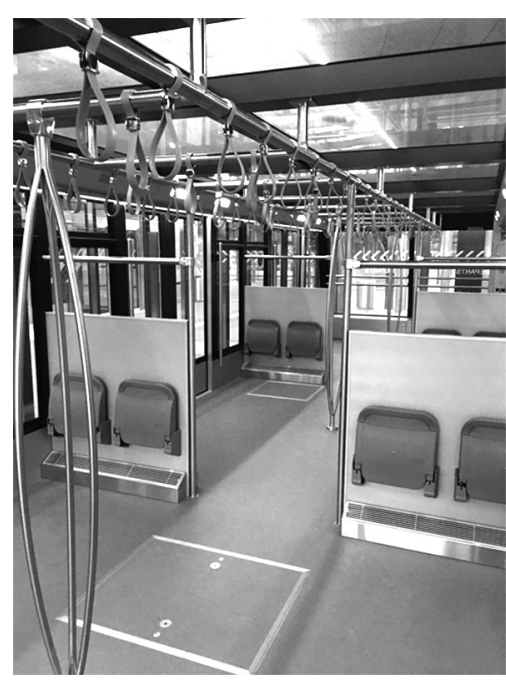

Figure 9: Funicular (Interior)

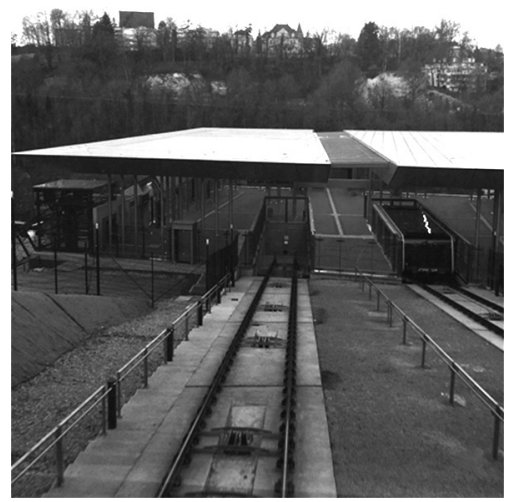

Figure 10: Funicular station (Train side)

ize a more environmentally friendly society. For that purpose, many parts of the rail track are covered with greenery (Figure 11) and cycle paths have been constructed along the system (Figure 12).

(Received September 10, 2020; accepted October 2, 2020)

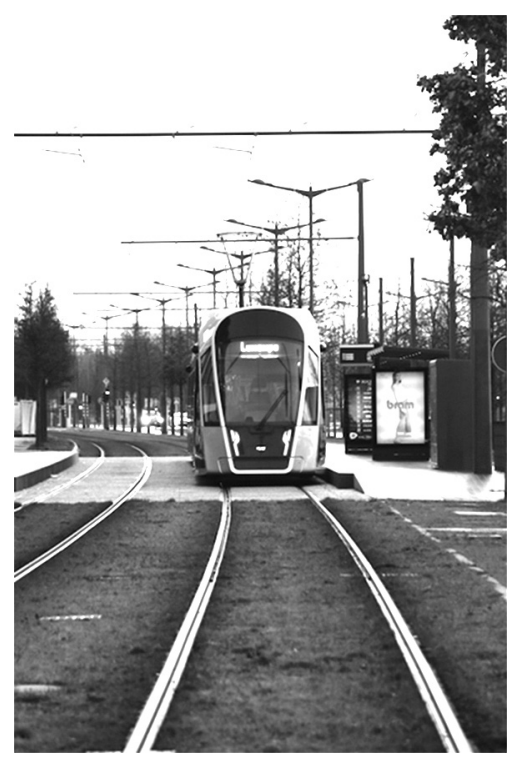

Figure 11: Greenery-covered track

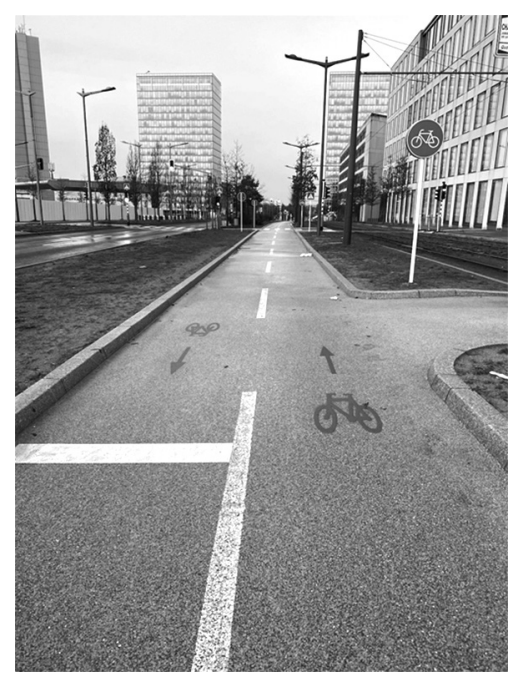

Figure 12: A newly constructed cycle path 